\title{
Intellectual capital: Concepts, components and indicators: A literature review
}

\author{
Mahdi Manzari, Mostafa Kazemi, Shamsoddin Nazemi and Alireza Pooya ${ }^{*}$
}

Faculty of Economics \& Administrative Sciences, Ferdowsi University of Mashhad, Mashhad, Iran

\begin{tabular}{l}
\hline A R T I C L E I N F O \\
\hline Article history: \\
Received April 20, 2012 \\
Accepted 21 July 2012 \\
Available online \\
July 22 2012 \\
\hline Keywords: \\
Intellectual capital \\
Human capital \\
Relational capital \\
Structural capital
\end{tabular}

\section{A B S T R A C T}

This paper presents a general review of intellectual capital literature, which includes definitions, components and indicators. We aim to gather a useful collection of indicators and definitions. After studying several related works from the literature, many definitions and indicators are identified and explain that choosing appropriate indicators depends on organizational targets. Every kind of organization can use this study to identify its more applicable and appropriate indicators to know about its intellectual capital. Identifying all of indicators in previous studies can help organization select right indicators for the organization.

\section{Introduction}

Today, organizations have identified two kinds of assets, which are important to measure: tangible and intangible assets. Intangible assets are not recorded in financial statements but constitute a high portion of the market value of the organization. Intellectual capital is one of the concepts, which is close to intangible assets. There have been tremendous efforts to measure intellectual capital, but lots of them are not general. In other words, instruments for measuring intellectual capital are specialized. The purpose of this study is to present a comprehensive review of intellectual capital concepts, components and their indicators. For this purpose, intellectual capital is divided into three components and every component is described, individually.

As companies entered into the 1990s, knowledge has became one of the most important strategic resources and one of the key economic resource and the dominant and perhaps even the only source of competitive advantage (Ramezan, 2011; Gavious \& Russ, 2009). Intellectual capital is said to be particularly important in a knowledge society (Bukh et al., 2001). Organizations should consider that the first step to change from a traditional company into a knowledge based company is to be aware of

* Corresponding author. Tel: +98 5118805351

E-mail addresses: alirezapooya@um.ac.ir (A. Pooya) 
the knowledge of the organization, also known as intellectual capital (IC) (Montequín et al., 2006). As organizations entered into the knowledge era, organizations understood that they should use their three kinds of capital (physical (tangible), financial and intellectual capital) to gain advantages over their competitors (Wall, 2005; Andriessen, 2004). Organizations of all kinds will need to become much better both at creating new intellectual capital and at using what they already have (Bartholomew, 2008).

IC operates as the most important contributor to justify the value difference between market value and book value of many organizations (Beattie \& Thomson, 2007; Bozbura et al., 2007; Mouritsen et al., 2001; Wall et al., 2004; Yang \& Lin, 2009). The intellectual capital of an organization has been reported to be three to four times over its book value (Edvinsson \& Malone 1997; Yang \& Lin, 2009). In a study of over 1000 firms by Brynjolfsson and Yang (1997), an increase of one dollar in the quantity of computer capital (tangible asset base) installed by a firm was found to be associated with an increase of up to ten dollars in the financial markets' valuation of the firm (Peppard \& Rylander, 2001). Understanding the real value of all assets provides a more accurate reflection of the worth of a company, which supports the corporate goals of transparency to shareholders, potential investors and market analysts (Ramezan, 2011).

This paper is organized as follow: section 2 represents a short review of intellectual capital historical background, importance and definitions, section 3 represents components of intellectual capital, section 4 represents conclusion of this study.

\section{Intellectual Capital}

Researchers have paid a great attention to the topic of intangible assets, often referred to as intellectual capital in the early 1990s. They mentioned its importance for all kinds of organizations like Microsoft, Astra, Rentokil and Oracle (Kim et al., 2010; Ramezan, 2011; Wall,2005; Chang \& Birkett, 2004 ; Alcaniz et al., 2011; Mouritsen et al., 2001). Edvinsson and Malone recommended intellectual capital for the Swedish financial company, Skandia, as a technique for quantifying the company's intangible assets (Peppard \& Rylander, 2001; Kitts et al., 2001). They devised a performance measurement index in five main areas; financial, human, customer, process and renewal. They emphasize the role of people in organizations and the importance of releasing human potential (Andriessen, 2007). According to Skandia's model, the hidden factors of human and structural capital comprise intellectual capital when added together (Bontis, 2001). Many other studies have conferred upon the importance and content of intellectual capital ( $\mathrm{Lu}$ et al., 2010). Intellectual capital has became critical to sustaining competitive advantage, organizational success, innovation, superior organizational performance, core differentiator operator, improve new product development performance, enhance shareholder value, create a framework that allows for describing all resources at the firm's disposal and how they interact to create value, organizational performance etc. (Ramezan,2011; Montequín et al., 2006; Bontis, 1998; Kim \& Kumar, 2009; Wall, 2005; Bozbura et al., 2007; Joia, 2007; Hsu \& Fang, 2009; Tai \& Chen, 2009; Lu et al.,2010; Bozbura \& Beskese, 2007; Lee, 2010; Peppard \& Rylander, 2001; Chen, 2009; Bozbura \& Beskese, 2007). However, the concept of intellectual capital is still unknown to many because it is difficult to measure in explicit terms (Lytras \& Pablos, 2009). In other words, there is no agreement on a common definition of IC (Peppard \& Rylander,2001; Kim et al., 2010; Beattie \& Thomson, 2007; Montequín et al., 2006; Meca \& Martinez, 2007; Beattie \& Thomson, 2007). 


\section{Table 1}

\section{Some definitions for IC}

\begin{tabular}{|c|}
\hline Definition \\
\hline $\begin{array}{l}\text { tellectual Capital is "those intangible assets of an organization that are not recorded in financial statements but which may } \\
\text { nstitute } 80 \% \text { of the market value of the organization". }\end{array}$ \\
\hline Intellectual capital is "the group of knowledge assets that are attributed to the value creation of an organization". \\
\hline Intellectual capital is "that asset based on knowledge and developed throughout flows among its different categories". \\
\hline $\begin{array}{l}\text { Intellectual capital is the "assets relating to employee knowledge and expertise, customer confidence in the company and its } \\
\text { products, brands, franchises, information systems, administrative procedures, patents, trademarks and the efficiency of } \\
\text { company business processes ". }\end{array}$ \\
\hline $\begin{array}{l}\text { Intellectual capital has been seen as "the combination of \&human capital, \& organizational capital and \&customer capital, } \\
\text { or simply as competence×commitment". }\end{array}$ \\
\hline $\begin{array}{l}\text { Intellectual capital is "the set of critical resources used by firms to facilitate productive activities and generate economic } \\
\text { rents". }\end{array}$ \\
\hline $\begin{array}{l}\text { Intellectual capital can be described as "intellectual material that has been formalized, captured and leveraged to produce a } \\
\text { higher-valued asset". }\end{array}$ \\
\hline $\begin{array}{l}\text { Intellectual capital is "a product of capacity which is the knowledge, skills, abilities, information and experience of } \\
\text { people; willingness of people to apply capacity; and opportunity provided by the work system to activate stocks of } \\
\text { intellectual capital". }\end{array}$ \\
\hline Intellectual capital is "knowledge-based equity of a company". \\
\hline $\begin{array}{l}\text { Intellectual capital is "the pursuit of effective use of knowledge the finished product as opposed to information the raw } \\
\text { material". }\end{array}$ \\
\hline $\begin{array}{l}\text { Intellectual capital is "sum of all knowledge-based factors i.e., resources, capabilities, and competences that are critical to } \\
\text { the creation of organizational value and a long-term, sustained, competitive advantage". }\end{array}$ \\
\hline Intellectual capital is "the collection of intangible resources and their flows". \\
\hline Intellectual capital is "the combined intangible assets, which enable the company to function". \\
\hline $\begin{array}{l}\text { Intellectual capital is "the assets relating to employee knowledge and expertise, customer confidence in the company and its } \\
\text { products, brands, franchises, information systems, administrative procedures, patents, trademarks and the efficiency of } \\
\text { company business processes". }\end{array}$ \\
\hline $\begin{array}{l}\text { Intellectual capital is "the future earning potential from a combination of human capital brains, skills, insights, and the } \\
\text { potential of an organization's people". }\end{array}$ \\
\hline capital is "the possession of kn \\
\hline
\end{tabular}

Intellectual capital is "a claim to future benefits that does not have a physical or financial embodiment".

Intellectual capital is "the term attributed to intangible assets which create company value".

Intellectual capital is "the intellectual resources that have been formalized, captured, and leveraged to create assets of higher value".

Intellectual capital has prevailed as "a measure of core competency and competitive advantage which explains the gap between the market value and book value of an organization at a time of decreasing usefulness of current financial reporting".

Intellectual capital is the "sum of the hidden assets of the company not fully captured on the balance sheet and that it is the most important source for sustainable competitive advantages in companies".

Intellectual capital is "the sum of the knowledge of its members and the practical translation of this knowledge into brands, trademarks and processes".

Intellectual capital is "all non-monetary and non-physical resources that are fully or partly controlled by the organization and that contribute to the organization's value creation".

Intellectual capital "refers to valuable, intangible and inimitable resources for value creation of a firm".

Intellectual capital "means anything an enterprise can use to increase its competitive advantage in the market place, including knowledge, information, intellectual property rights and experience. In other words, IC is presented as intangible assets and it produces value to enterprises that can be reflected as final income in financial statements, but it cannot be expressed as an accounting title in financial statements".

Intellectual capital is "the packaged useful knowledge".

Intellectual capital is "intellectual material - knowledge, information, intellectual property, experience - that can be put to use to create wealth".

Intellectual capital is" the resource that comes from the knowledge, experience and transferable competencies of its staff, from the organization's ability to innovate and manage change, from its infrastructure, and from relationships between stakeholders and partners".

Intellectual capital is "the knowledge that can be converted into profits".

Intellectual capital is "the enhanced value of a firm attributable to assets, generally of an intangible nature, resulting from the companies organizational function, processes and information technology networks, the competency and efficiency of its employees and its relationship with its customers".

Intellectual capital is "the knowledge that can be converted into profits".

Intellectual capital is "equal to a company's core competencies".

Intellectual capital "consists of assets created through intellectual activities ranging from acquiring new knowledge learning and inventions to creating valuable relationships".

Intellectual capital is "the knowledge and knowing capability of a social collectivity, for example an organization, intellectual community, or professional practice".

Reference

Torres, 2006

Chu et al., 2006

Rudez \& Mihalic, 2007

Bozbura \& Beskese, 2007

Bukh et al., 2001

Peng et al., 2007

Martin, 2000

Burr \& Girardi, 2002

Bartholomew, 2008

Bartholomew, 2008

Lytras \& Pablos, 2009

Rudez \& Mihalic, 2007

Gavious \& Russ, 2009

Bartholomew, 2008

Burr \& Girardi, 2002

Rudez \& Mihalic, 2007;

Montequín et al., 2006;Kim,

et al., 2010; Bontis, 2001;

Andriessen, 2004

Rudez \& Mihalic, 2007

Beattie \& Thomson, 2007

Kim et al., 2010

Han \& Han, 2004

Peng et al., 2007

Andriessen, 2004

Peng et al., 2007

Peng et al., 2007

Lu et al., 2010

Andriessen, 2004

Tai \& Chen, 2009; Bontis,

1998; Bukh et al., 2001;

Yang \& Lin, 2009; Bontis,

2001; Burr \& Girardi, 2002

Lee, 2010

Andriessen, 2004

Gavious \& Russ, 2009

Baker, 2008

Andriessen, 2004

Tai \& Chen, 2009;

Montequín et al., 2006

Chen, 2009

Joia (2007) suggest that the multidimensional nature of intellectual capital, as defined by many members of the community, is often not well understood, which means definitions are not always 
very clear and there are no boundaries of what people mean when they talk about intellectual capital (Joia, 2007). Intellectual capital has been defined from different perspectives, focusing on the analysis level (individual or organizational), the perception of the value of time (current value or future value), and objectivity (input or output) (Kim \& Kumar, 2009). After reviewing existing literature on this topic, some definitions have been revealed that are represented in Table 1.

\section{Components \& Models}

Several contributions have provided different frameworks for classifying the different components of intellectual capital (Ramezan, 2011). Despite the lack of a common definition for intellectual capital, many researchers accept that there are three major categories for intellectual capital: human capital, structural (or organizational) capital and relational (or customer) capital (Beattie \& Thomson, 2007; Wall, 2005; Kim et al., 2010; Rudez \& Mihalic, 2007; Chu et al., 2006; Tai \& Chen,2009; Torres, 2006). However, there are other categories include: process capital, innovation, research, and development capital (Tai \& Chen, 2009; Meca \& Martinez, 2007) end customer-relationship capital and non-end-customer-relationship capital (Rudez \& Mihalic, 2007), Business capital (Ramezan, 2011), Social capital (Ramezan, 2011; Baker, 2008) strategy capital (Meca \& Martinez, 2007), etc. Fig. 1 represents Skandia's value scheme.

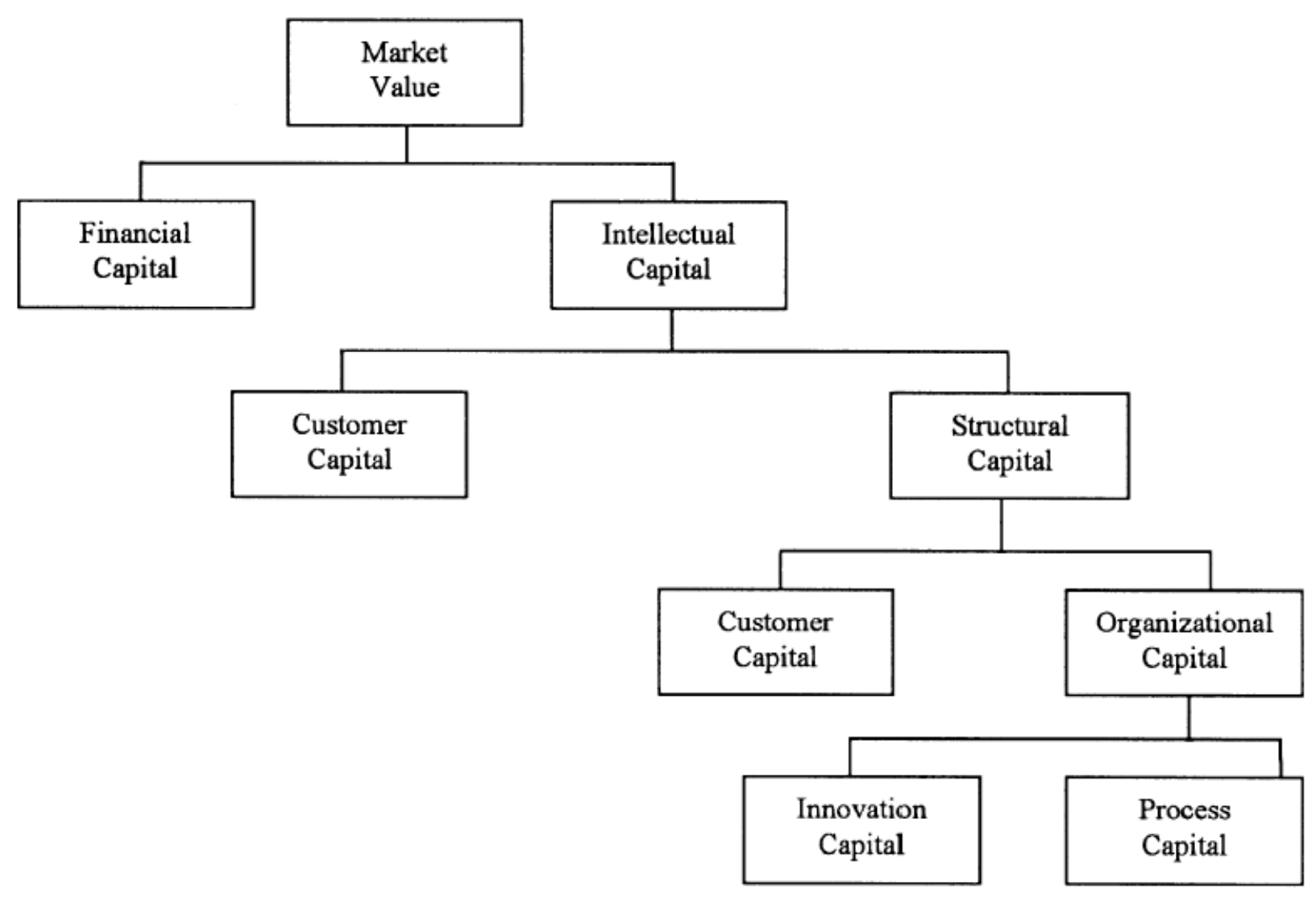

Fig. 1. Skandia's value scheme (Source: Bontis, 2001)

Such categorization in intellectual capital can help in making decisions about the actions that the firm must perform and about the implementation of programs that allow maintenance, leverage and building of those more valuable intangible assets (or intellectual capital). Hence, in order to explore the relationships between any specific kind of intellectual capital and competitive advantage, a clear identification of the main components of intellectual capital is required (Chen,2009). There are some 
definitions for three major components of intellectual capital. Table 2, 4 and 6 represent some of these definitions.

\subsection{Human Capital}

Human capital is the core asset of an organization (Yang \& Lin, 2009) that was originally used by Nobel economist Gary Becker (1964) to refer to the stored value of knowledge and skills of members of the US workforce (Smart, 1999). As one industry leader said, this is the capital that leaves in the elevator at night (Baker, 2008). In fact, human capital is a matter of survival and success in all of the organizations (Meca \& Martinez, 2007; Gavious \& Russ, 2009; Luo et al., 2009, Doong et al., 2010; Yang \& Lin, 2009). Therefore, keeping knowledge of workers and knowledge workers are important issues for companies to maintain their human capital. Some of the results of having higher human capital are: increase organizational performance (Becker, 1964; Lim et al., 2010; Doong et al., 2010; Smart, 1999; Bozbura et al., 2007; Zula \& Chermack, 2007), strengthening core competence, increasing success of organizations (Zula \& Chermack, 2007), sustaining organization competitive advantage (Yang \& Lin, 2009; Kim et al., 2010; Zula \& Chermack, 2007), significant positive effects on financial performance (Doong et al., 2010; Bozbura et al., 2007; Zula \& Chermack, 2007; Gavious \& Russ,2009), strategic renewal (Ramezan, 2011; Kim et al., 2010, Bontis, 1998), source of creativity and innovation (Mouritsen et al., 2001; Ramezan, 2011; Kim et al., 2010, Bontis, 1998; Zula \& Chermack, 2007).

Despite the importance of human capital for organizations, there is no common definition for it as well as indicators of human capital. Kim et al. (2010) suggest that human capital focuses on the economic value of what the employees can produce and represents the individual and collective competence of employees (Kim et al., 2010). Martin (2000) proposes that human capital resides in employees who are doing work that adds value for customers (Martin, 2000). Some definitions for human capital are presented in Table 2.

Many indicators for measuring human capital have been used in different organizations. Meca \& Martinez (2007) propose that human capital elements vary significantly depending on the type of company; they may be more important for some firms and less important for others (Meca \& Martinez, 2007). Among many definitions and papers, seven categories specified by the authors including Attitude \& Motivation, Competence, Skill, Capabilities, Creativity \& Innovativeness, Experience \& Expertise, Individual personal characteristics, Knowledge and Efficiency

- Attitude \& Motivation

- Competence, Skill, Capabilities

- Creativity \& Innovativeness

- Experience \& Expertise

- Individual personal characteristics

- Knowledge

- Efficiency

Next, we present some indictors that are extracted from previous studies. 
Table 2

Some definitions for human capital

\begin{tabular}{|c|c|}
\hline Resource & Definition \\
\hline $\begin{array}{l}\text { Martinez-Torres, } \\
2006\end{array}$ & $\begin{array}{l}\text { Human capital is "the individual-level knowledge, such as professional skills, experience, and innovativeness that each employee } \\
\text { possesses". }\end{array}$ \\
\hline $\begin{array}{l}\text { Rudez \& } \\
\text { Mihalic, } 2007\end{array}$ & Human capital is represented by the "intangible assets embodied by individuals". \\
\hline Ramezan, 2011 & $\begin{array}{l}\text { Human capital makes reference to "the tacit or explicit knowledge which people possess, as well as their ability to generate it, } \\
\text { which is useful for the mission of the organization and includes values and attitudes, aptitudes and know-how". }\end{array}$ \\
\hline Chu et al., 2006 & $\begin{array}{l}\text { The term human capital refers to the "knowledge, seniority, mobility rate, skills, and experiences of the entire organization's } \\
\text { staff and management". }\end{array}$ \\
\hline Ramezan, 2011 & Human capital includes "values and attitudes, aptitudes and know-how". \\
\hline $\begin{array}{l}\text { Bozbura \& } \\
\text { Beskese, } 2007\end{array}$ & Human capital is "the individual-level knowledge that each employee possesses". \\
\hline Baker, 2008 & Human capital "is owned by the knowledge worker". \\
\hline Joia, 2007 & uman capital is "those components refer to the skills and c \\
\hline Ricceri, 2008 & $\begin{array}{l}\text { Human capital is "the knowledge that employees take with them when they leave the firm. Includes the knowledge, skills, } \\
\text { experiences and abilities of people. Some of this knowledge is unique to the individual, some may be generic. Examples are } \\
\text { innovation capacity, creativity, know-how and previous experience, teamwork capacity, employee flexibility, tolerance of } \\
\text { ambiguity, motivation, satisfaction, learning capacity, loyalty, formal training and education". }\end{array}$ \\
\hline $\begin{array}{l}\text { Zula \& } \\
\text { Chermack, } 2007\end{array}$ & $\begin{array}{l}\text { Human Capital is "the knowledge and skills that people acquire through education and training as being a form of capital, and this } \\
\text { capital is a product of deliberate investment that yields returns". }\end{array}$ \\
\hline Ramezan, 2011 & uman capital presents "the individual tacit knowledge embedded in the mind of the employees". \\
\hline Ramezan, 2011 & Human capital can be defined as "a combination of employee's competence, attitude and creativity". \\
\hline Smart, 1999 & Human capital is the "propensity of a person or group to perform behaviors that are valued by an organization". \\
\hline Bontis, 2001 & $\begin{array}{l}\text { Human Capital is defined as "the combined knowledge, skill, innovativeness and ability of the company's individual employees to } \\
\text { meet the task at hand. It also includes the company's values, culture and philosophy. Human capital cannot be owned by the } \\
\text { company". }\end{array}$ \\
\hline Lim et al., 2010 & $\begin{array}{l}\text { Human capital refers to "the stock of usable knowledge, skills, capabilities, productivity of an organization and competencies for } \\
\text { individuals and for groups that sustain an organization's wealth". }\end{array}$ \\
\hline Lim et al., 2010 & $\begin{array}{l}\text { Human capital is "the combined knowledge, wisdom, expertise, skill, intuition, innovativeness, and ability of the individuals to } \\
\text { meet the tasks and goals at hand, which include values, culture, and philosophy". }\end{array}$ \\
\hline Lim et al., 2010 & $\begin{array}{l}\text { Human capital is the "individual's or firm's collective capability to extract the best solutions from the knowledge of its people, and } \\
\text { represents the creativity and innovativeness that exist in each employee's mind to provide solutions to customers". }\end{array}$ \\
\hline Massie 2001 & Human capital is often defined as "the productive capacity imbedded in an individual". \\
\hline Chen, 2009 & Human capital represents the individual knowledge stock of an organization as represented \\
\hline $\begin{array}{l}\text { Montequín et al., } \\
2006\end{array}$ & man capital describes "the value of the know-how and competences of an organization's e \\
\hline
\end{tabular}

\subsection{Attitude \& Motivation}

This category has been addressed by many ((Kim et al.,2010;Beattie \& Thomson, 2007; Martin, 2000; Rudez \& Mihalic, 2007; Ramezan, 2011; Kim and Kumar, 2009; Cabrilo et al., 2009; Lim et al., 2010; Han \& Han, 2004) and different factors are discussed by various researchers.

\begin{tabular}{|c|c|}
\hline Factor & Researcher(s) \\
\hline Ability to attract talented people & (Lim et al.,2010) \\
\hline Absence / Leaving rate & (Beattie \& Thomson, 2007;Guthrie \& Petty,2000;Tai \& Chen,2009;Lim et al.,2010) \\
\hline Agreements with employees & (Meca \& Martinez, 2007) \\
\hline Career opportunities & (Meca \& Martinez, 2007) \\
\hline Commitment & (Beattie \& Thomson, 2007;Lim et al.,2010;Kim and Kumar,2009) \\
\hline Employee relations & (Beattie \& Thomson, 2007;Guthrie \& Petty,2000; Peng et al.,2007) \\
\hline Employee safety & (Beattie \& Thomson, 2007) \\
\hline $\begin{array}{l}\text { Employee compensation (welfare, wages \& salaries, } \\
\text { Insurance, Pensions) }\end{array}$ & (Lim et al.,2010 ;Beattie \& Thomson, 2007; Meca \& Martinez, 2007) \\
\hline Empowerment & (Lim et al.,2010) \\
\hline $\begin{array}{l}\text { Equity issues (race, gender, religion and disability } \\
\text { issues) }\end{array}$ & (Beattie \& Thomson, 2007) \\
\hline Identification & (Beattie \& Thomson, 2007) \\
\hline Job rotation opportunities & (Meca \& Martinez, 2007) \\
\hline Leadership index & $\begin{array}{l}\text { (Han \& Han,2004;Lim et al.,2010 ;Bozbura \& Beskese,2007;Kim and Kumar,2009;Cabrilo et al.,2009; } \\
\text { Peng et al.,2007) }\end{array}$ \\
\hline Perceptions & (Beattie \& Thomson, 2007) \\
\hline Recruitment Policy & (Beattie \& Thomson, 2007; Meca \& Martinez, 2007) \\
\hline Remuneration systems & (Meca \& Martinez, 2007) \\
\hline Reputation of company employees with head-hunters & (Lim et al.,2010) \\
\hline Retention of key personnel & (Lim et al.,2010) \\
\hline Satisfaction & (Wall,2005;Lim et al.,2010;Beattie \& Thomson, 2007;Guthrie \& Petty,2000;Kim and Kumar,2009) \\
\hline Staff capacity maximization & (Lim et al.,2010) \\
\hline Strategic alignment. & (Cabrilo et al.,2009) \\
\hline Turnover ratios / staff stability & $\begin{array}{l}\text { (Martin,2000;Wall,2005;Beattie \& Thomson, 2007;Lim et al.,2010 ;Lu et al.,2010; Montequín et } \\
\text { al.,2006) }\end{array}$ \\
\hline
\end{tabular}




\subsection{Competence, Skill, Capabilities}

This item has been investigated by several researchers (Beattie \& Thomson, 2007; Montequín et al., 2006; Chen, 2009, Guthrie \& Petty, 2000; Peng et al., 2007; Bozbyra \& Beskese, 2007; Rudez \& Mihalic, 2007; Kim \& Kumar, 2009; Meca \& Martinez, 2007; Ramezan, 2011; Peng et al., 2007; Kim et al., 2010).

\begin{tabular}{|c|c|}
\hline Factor & Researchers \\
\hline Aptitude of staff & Wall, 2005; Montequín et al., 2006 \\
\hline Communicative abilities & Beattie \& Thomson, 2007 \\
\hline Dependence on key employees & Meca \& Martinez, 2007 \\
\hline Development & Beattie \& Thomson, 2007;Wall, 2005 \\
\hline Flexibility / Changeability & Beattie \& Thomson, 2007; Peng et al., 2007 \\
\hline Human resources / Human assets & Beattie \& Thomson, 2007 \\
\hline Learning capacity & Lim et al., 2010 \\
\hline Management credibility & Lim et al., 2010 \\
\hline Managerial talent of administrative staff & Peng et al., 2007 \\
\hline New comers & Lim et al., 2010 \\
\hline Number of senior positions filled by junior staff & Wall, 2005;Lim et al., 2010 \\
\hline Percentage of persons receiving variable earned income & Lim et al., 2010 \\
\hline Proactive and reactive abilities & Lim et al., 2010 \\
\hline Reputation & Peng et al., 2007 \\
\hline Social skills & Cabrilo et al., 2009;Beattie \& Thomson, 2007 \\
\hline Staff profile & Beattie \& Thomson, 2007 \\
\hline Staff with professional qualifications & Wall, 2005;Guthrie \& Petty, 2000;Lim et al., 2010;Beattie \& Thomson, 2007 \\
\hline Taking responsibility & Beattie \& Thomson, 2007 \\
\hline tenure & Martin, 2000 \\
\hline time to fill an open position; & Guthrie \& Petty, 2000 \\
\hline Work-related competencies & Beattie \& Thomson, 2007;Guthrie \& Petty, 2000;Lim et al., 2010 \\
\hline
\end{tabular}

\subsection{Creativity \& Innovativeness}

Creativity \& Innovativeness is another item influencing human capital and there are different factors associated with this factor as follows,

\begin{tabular}{ll}
\hline Factor & Researchers \\
\hline Employees who are able to translate customer needs into products & Lim et al., 2010 \\
Entrepreneurial spirit & Guthrie \& Petty, 2000; Lim et al., 2010; Beattie \& Thomson, 2007 \\
Intellectual agility & Kim et al., 2010 \\
New ideas generated by members of staff & Wall, 2005; Lim et al., 2010 \\
Organizational patents, trademarks & Chen, 2009 \\
Paper/ Patent per employee & Kim \& Kumar, 2009 \\
\hline
\end{tabular}

\subsection{Efficiency}

According to Cabrilo et al. (2009), different efficiency factors are discussed as follows,

\begin{tabular}{|c|c|c|c|}
\hline Factor & Researchers & Researchers & \\
\hline $\begin{array}{l}\text { Full-time or permanent employees who spend } \\
\text { less than } 50 \% \text { of work hours at a corporate } \\
\text { facility }\end{array}$ & Lim et al., 2010 & Production/Income per employee & Meca \& Martinez, 2007 \\
\hline Hours spent in debriefing \& Orienting & Lim et al., 2010 & Productivity & Beattie \& Thomson, 2007 \\
\hline Improvement systems & Kim et al., 2010 & Quality performance ratios & Lim et al., 2010 \\
\hline Measures of cycle time for key HR processes; & Guthrie \& Petty, 2000 & Ratio of wages or salary to total cost & Lim et al., 2010 \\
\hline Number of managers & Lim et al., 2010 & Revenue per patent & Lim et al., 2010 \\
\hline $\begin{array}{l}\text { Number or percentage of full-time, contract or } \\
\text { temporary staff }\end{array}$ & $\begin{array}{l}\text { Lu et al., 2010; Meca \& Martinez, } \\
\text { 2007;Beattie \& Thomson, 2007;Lim } \\
\text { et al., } 2010\end{array}$ & Staff capacity utilization & Lim et al., 2010 \\
\hline Organizational infrastructure & Chen, 2009 & Stakeholder satisfaction indicators & Lim et al., 2010 \\
\hline $\begin{array}{l}\text { Percentage of correct entries on HR information } \\
\text { systems. }\end{array}$ & Guthrie \& Petty, 2000 & Standards contribution per man & Kim and Kumar, 2009 \\
\hline $\begin{array}{l}\text { Percentage of employee development plans } \\
\text { completed; }\end{array}$ & Guthrie \& Petty, 2000 & $\begin{array}{l}\text { Star employees their performance equals } \\
\text { two times the performance of their } \\
\text { colleagues }\end{array}$ & Lim et al., 2010 \\
\hline $\begin{array}{l}\text { Percentage of persons who are subject to a } \\
\text { system of earned income according to } \\
\text { objectives }\end{array}$ & Lim et al., 2010 & $\begin{array}{l}\text { Superstar employees their performance } \\
\text { equals four times the performance of } \\
\text { their colleagues }\end{array}$ & Lim et al., 2010 \\
\hline Performance & Kim et al., 2010;Guthrie \& Petty, 2000 & total HR investments/revenue; & Guthrie \& Petty, 2000 \\
\hline Processing time for administrative tasks & Lim et al., 2010 & Value added per employee & $\begin{array}{l}\text { Wall, 2005, Lim et al., 2010;Tai } \\
\text { \& Chen, 2009;Beattie \& } \\
\text { Thomson, 2007;Meca \& } \\
\text { Martinez, 2007 }\end{array}$ \\
\hline
\end{tabular}




\subsection{Experience \& Expertise}

Experience and expertise are another important components of human capital (Cabrilo et al., 2009; Bozbura \& Beskese, 2007; Martin, 2000; Lim et al., 2010; Meca \& Martinez, 2007; Lu et al., 2010; Wall, 2005; Asonitis et al., 2010; Kim \& Kumar, 2009; Beattie \& Thomson, 2007; Chen, 2009).

\begin{tabular}{|c|c|}
\hline Factor & Researchers \\
\hline Average duration of employment & Lim et al., 2010 \\
\hline Effectiveness of learning transfer in key areas & Lim et al., 2010 \\
\hline Empowered teams & Beattie \& Thomson, 2007;Asonitis et al., 2010;Lim et al., 2010 \\
\hline Expert networks & Beattie \& Thomson, 2007 \\
\hline Management & Beattie \& Thomson, 2007 \\
\hline Replacement costs of key personnel & Lim et al., 2010 \\
\hline $\begin{array}{l}\text { Rookie ratio percent of employees with less } \\
\text { than } 2 \text { years of experience }\end{array}$ & Lim et al., 2010 \\
\hline Reflect experiences previous & Beattie \& Thomson, 2007 \\
\hline
\end{tabular}

\subsection{Individual personal characteristics}

Individual personal characteristics in the other human capital addressed by many researchers and the factors are addressed by the following,

\begin{tabular}{|c|c|}
\hline Factor & Researchers \\
\hline Average age of staff & Lim et al., 2010; Beattie \& Thomson, 2007; Meca \& Martinez, 2007 \\
\hline Company diversification index & Lim et al., 2010 \\
\hline $\begin{array}{l}\text { Men/women diversity // Ratio of men and } \\
\text { women in management }\end{array}$ & Lim et al., 2010 \\
\hline Risk-taking and problem solving capabilities & Bozbura \& Beskese, 2007 \\
\hline Sensitivity & Beattie \& Thomson, 2007 \\
\hline Talent & Lim et al., 2010 \\
\hline Tolerance for ambiguity & Beattie \& Thomson, 2007 \\
\hline
\end{tabular}

\subsection{Knowledge}

Knowledge is the component of human capital (Beattie \& Thomson, 2007; Chen, 2009) with the following factors,

\begin{tabular}{|c|c|}
\hline Factor & Researchers \\
\hline $\begin{array}{l}\text { Background variety index individual and } \\
\text { group level }\end{array}$ & Lim et al., 2010 \\
\hline $\begin{array}{l}\text { Company managers with advanced degrees: } \\
\text { business, science and engineering, liberal arts }\end{array}$ & Lim et al., 2010 \\
\hline Creating results by using knowledge; & Guthrie \& Petty, 2000 \\
\hline Education & $\begin{array}{l}\text { Bozbura \& Beskese, 2007; Guthrie \& Petty, 2000; Lim et al., 2010; } \\
\text { Beattie \& Thomson, 2007; Asonitis et al., 2010; Meca \& Martinez, } \\
\text { 2007; Kim \& Kumar, 2009 }\end{array}$ \\
\hline Individual-level knowledge & Bozbura \& Beskese, 2007 \\
\hline IT literacy & Han \& Han, 2004; Lim et al., 2010; Beattie \& Thomson, 2007 \\
\hline Know-how employees & Beattie \& Thomson, 2007; Guthrie \& Petty, 2000; Lim et al., 2010 \\
\hline Knowledge sharing. & Cabrilo et al., 2009; Guthrie \& Petty, 2000 \\
\hline Number of certified employees & Lim et al., 2010 \\
\hline Organizational learning & Lim et al., 2010 \\
\hline Structural knowledge & Beattie \& Thomson, 2007 \\
\hline Training & $\begin{array}{l}\text { Beattie \& Thomson, 2007; Lim et al., 2010; Guthrie \& Petty, 2000; } \\
\text { Tai \& Chen, 2009; Kim et al., 2010; Wall, } 2005\end{array}$ \\
\hline Work-related knowledge & Beattie \& Thomson, 2007; Guthrie \& Petty, 2000; Lim et al., 2010 \\
\hline
\end{tabular}




\subsection{Relational Capital}

Initially relational capital was under structural capital in the original model of Edvinsson and Malone (1997). However, Bozbura (2004) argued that relational capital should be separated from structural capital to conduct further discussion (Chen, 2009). In some researches, relational capital is represented as customer capital (Tai \& Chen, 2009; Han \& Han, 2004; Ramezan, 2011; Martin, 2000; Bontis, 1998; Kim et al., 2010; Wall, 2005). According to Chen et al. (2004), customer capital is the main determinant in the conversion of intellectual capital into market value, acting as a bridge and catalyst on the operations of intellectual capital. Compared with human and organizational capital, customer capital has a more direct effect on a company's value and organizational performance (Bontis, 1998). Also, customer capital can be the foundation for capturing insight into the future need for customer services. Organizations create customer capital through the relationships that are developed between their internal agents (i.e. management and employees) and their customers (Chang \& Tseng, 2005; Duffy, 2000; Kim et al., 2010). There are many definitions for relational capital. Some of relational capital definitions are presented in Table 4.

\section{Table 4}

Relational (Customer) Capital Definitions

No Researchers Definition

\begin{tabular}{|c|c|c|}
\hline 1 & $\begin{array}{l}\text { Martinez-Torres, 2006; } \\
\text { Bozbura \& Beskese, 2007; } \\
\text { Lee, } 2010\end{array}$ & $\begin{array}{l}\text { Relational capital is "the sum of all assets that arrange and manage the firm's } \\
\text { relations with the environment. The relational capital contains the relations with } \\
\text { customers, suppliers, shareholders, the rival, community, the official } \\
\text { institutions, and society". }\end{array}$ \\
\hline 2 & Chen, 2009 & $\begin{array}{l}\text { Relational capital is "the summation of relationships, interactions, and intimacy } \\
\text { of an organization with internal and external stakeholders; that is to say, relational } \\
\text { capital which embraces all the relations the firm has established with its stakeholder } \\
\text { groups such as customers, suppliers, the community, the government, etc". }\end{array}$ \\
\hline 3 & $\begin{array}{l}\text { Chang \& Tseng, 2005; } \\
\text { Engstrom et al., 2003; Kim } \\
\text { et al., } 2010\end{array}$ & $\begin{array}{l}\text { Customer capital is "the value that contributes to current and future revenues, } \\
\text { resulting from an organization's relationship with its customers". }\end{array}$ \\
\hline 4 & $\begin{array}{l}\text { Bontis et al., 2000; Kim et } \\
\text { al., } 2010\end{array}$ & $\begin{array}{l}\text { Customer capital is "the knowledge embedded in the marketing channels and } \\
\text { customer relationships that an organization develops through the course of } \\
\text { conducting business". }\end{array}$ \\
\hline 5 & Rudez \& Mihalic, 2007 & $\begin{array}{l}\text { Customer capital "is constituted by customer satisfaction and loyalty, image and } \\
\text { brand, and direct distribution channels. Customer capital can be broadened to } \\
\text { relationship capital, which also includes relationships with other subjects such as } \\
\text { business partners, tourism promotion organizations, government, local } \\
\text { community, competitors, creditors, special interest groups, the media and the } \\
\text { public". }\end{array}$ \\
\hline 6 & Chu et al., 2006 & $\begin{array}{l}\text { The term relational capital "refers to the organization's establishment, } \\
\text { maintenance, and development of public relations matters, including the degree } \\
\text { of customer, supplier, and strategic partner satisfaction, as well as the merger of } \\
\text { value and customer loyalty". }\end{array}$ \\
\hline 7 & Ramezan, 2011 & $\begin{array}{l}\text { Relational capital "gathers the value of the relationships that the firm maintains with } \\
\text { external agents business activity close by or with other more distant social agents". }\end{array}$ \\
\hline 8 & Joia, 2007 & $\begin{array}{l}\text { Relationship capital components "refer to relationships with customers or other } \\
\text { stakeholders". }\end{array}$ \\
\hline 9 & Beattie \& Thomson, 2007 & $\begin{array}{l}\text { Relational capital is "all resources linked to the external relationships of the firm, } \\
\text { with customers, suppliers or R\&D partners. Comprises that part of human and } \\
\text { structural capital involved with the company's relations with stakeholders investors, } \\
\text { creditors, customers, suppliers, etc. plus the perceptions that they hold about the } \\
\text { company". }\end{array}$ \\
\hline
\end{tabular}


Among many definitions and papers, seven categories specified by the authors including customers, stakeholders, corporate identity, internal issues, market presence and business contracts and suppliers. Table 5 represents relational capital indicators for each category.

\section{Table 5}

Indicators of each category for relational (customer) capital

\begin{tabular}{|c|c|c|}
\hline Category & Factor & Resource \\
\hline \multirow{12}{*}{ Customer } & Customer loyalty & $\begin{array}{l}\text { Tai \& Chen, 2009; Beattie \& Thomson, 2007; Bozbura \& Beskese, 2007; Martin, } \\
\text { 2000; Guthrie \& Petty, 2000; Singh \& Kansal, 2011; Bozbura et al., 2007; Cabrilo et al., } \\
\text { 2009; Chen, 2009; Ortiz, 2009; Kim et al., } 2010\end{array}$ \\
\hline & customer relationship & Ramezan, 2011; Bontis, 1998; Asonitis \& Kostagiolas, 2010; Chen, 2009; Ortiz, 2009 \\
\hline & Customer complaint & Ramezan, 2011; Cabrilo et al., 2009; Wall, 2005 \\
\hline & Customer database & Ramezan, 2011; Ortiz, 2009; Beattie \& Thomson, 2007 \\
\hline & Customer retention rate & Han \& Han, 2004; Ramezan, 2011; Kim and Kumar, 2009; Kim et al., 2010 \\
\hline & Customer satisfaction & $\begin{array}{l}\text { Tai \& Chen, 2009; Han \& Han, 2004; Beattie \& Thomson, 2007; Ramezan, 2011; } \\
\text { Cabrilo et al., 2009; Kim \& Kumar, 2009; Kim et al., 2010; Wall, } 2005\end{array}$ \\
\hline & Customer service capability & Ramezan, 2011 \\
\hline & customer's needs Identifying & Beattie \& Thomson, 2007; Ramezan, 2011 \\
\hline & Customers & $\begin{array}{l}\text {,Tai \& Chen, 2009; Han \& Han, 2004; Beattie \& Thomson, 2007; Bozbura \& Beskese, } \\
\text { 2007; Guthrie \& Petty, 2000; Singh \& Kansal, 2011; Bozbura et al., 2007; Wall, } 2005\end{array}$ \\
\hline & New strategic customers & Beattie \& Thomson, 2007 \\
\hline & Unit sales to customer Average revenue per unit & Ramezan, 2011, Kim \& Kumar, 2009; Cabrilo et al., 2009; Han \& Han, 2004 \\
\hline & Patients & Peng et al., 2007 \\
\hline \multirow{4}{*}{ Stakeholders } & Knowledge/acquaintance with community & Beattie \& Thomson, 2007; Chen, 2009 \\
\hline & Knowledge/acquaintance with government & Beattie \& Thomson, 2007; Cabrilo et al., 2009; Peng et al., 2007; Bozbura et al., 2007 \\
\hline & Society Environmental activities & $\begin{array}{l}\text { „Bozbura \& Beskese, 2007; Beattie \& Thomson, 2007; Bozbura et al., 2007; Lee, } \\
\text { 2010; Peng et al., 2007; Asonitis \& Kostagiolas, } 2010\end{array}$ \\
\hline & international scientists & Lee, 2010 \\
\hline \multirow{8}{*}{$\begin{array}{l}\text { Corporation } \\
\text { Identity }\end{array}$} & Brands & $\begin{array}{l}\text {,Tai \& Chen, 2009; Beattie \& Thomson, 2007; Ramezan, 2011; Guthrie \& Petty, } \\
\text { 2000; Singh \& Kansal, 2011; Watson \& Stanworth, 2006; Kim \& Kumar, 2009; } \\
\text { Asonitis \& Kostagiolas, 2010; Kim et al., } 2010\end{array}$ \\
\hline & Company names & Beattie \& Thomson, 2007; Guthrie \& Petty, 2000; Singh \& Kansal, 2011; Ortiz, 2009 \\
\hline & conference activities & Lee, 2010; Peng et al., 2007 \\
\hline & Customer names \& reputation & Beattie \& Thomson, 2007 \\
\hline & Image & $\begin{array}{l}\text { Beattie \& Thomson, 2007; Cabrilo et al., 2009; Asonitis \& Kostagiolas, 2010; Ortiz, } \\
\text { 2009; Kim et al., 2010; Wall, } 2005\end{array}$ \\
\hline & Media Advertising. & Peng et al., 2007; Ortiz, 2009; Wall, 2005 \\
\hline & quality standards & Beattie \& Thomson, 2007; Ortiz, 2009 \\
\hline & Transparency of organization & Wall, 2005 \\
\hline \multirow{3}{*}{ Internal Issues } & Corporate culture & Ortiz, 2009 \\
\hline & Top management team & Peng et al., 2007 \\
\hline & Shareholders Stakeholders & Bozbura \& Beskese, 2007; Beattie \& Thomson, 2007; Bozburaet al., 2007 \\
\hline \multirow{16}{*}{$\begin{array}{l}\text { Market } \\
\text { Presence and } \\
\text { Business } \\
\text { Contracts }\end{array}$} & Basic marketing capability & Han \& Han, 2004; Beattie \& Thomson, 2007 \\
\hline & Connectivity & Beattie \& Thomson, 2007; Martin, 2000; Ortiz, 2009 \\
\hline & Distribution channels & $\begin{array}{l}\text { Beattie \& Thomson, 2007; Guthrie \& Petty, 2000; Singh \& Kansal, 2011; Ortiz, 2009; } \\
\text { Kim et al., } 2010\end{array}$ \\
\hline & Favorable contracts & Beattie \& Thomson, 2007; Guthrie \& Petty, 2000; Singh \& Kansal, 2011 \\
\hline & Financial contracts & Beattie \& Thomson, 2007 \\
\hline & Franchising agreements & $\begin{array}{l}\text {,Beattie \& Thomson, 2007; Guthrie \& Petty, 2000; Singh \& Kansal, 2011; Ortiz, } \\
2009\end{array}$ \\
\hline & Licensing agreements & $\begin{array}{l}\text { Beattie \& Thomson, 2007; Guthrie \& Petty, 2000; Singh \& Kansal, 2011; Kim and } \\
\text { Kumar, 2009; Ortiz, } 2009\end{array}$ \\
\hline & Market & Bozbura \& Beskese, 2007; Bozbura et al., 2007; Bontis, 1998 \\
\hline & Market intensity & Beattie \& Thomson, 2007 \\
\hline & Market orientation & Kim et al., 2010 \\
\hline & Market potential & Ramezan, 2011 \\
\hline & Market Share & $\begin{array}{l}\text { Tai \& Chen, 2009; Beattie \& Thomson, 2007; Ramezan, 2011; Cabrilo et al., 2009; } \\
\text { Kim et al., } 2010\end{array}$ \\
\hline & Networking & Beattie \& Thomson, 2007; Ortiz, 2009 \\
\hline & sales channel & Ramezan, 2011 \\
\hline & tech licenseNum. of & Kim \& Kumar, 2009 \\
\hline & CompetitorsCompetitive intelligence & Beattie \& Thomson, 2007; Peng et al., 2007 \\
\hline \multirow{5}{*}{ Suppliers } & Research collaborations & Beattie \& Thomson, 2007 \\
\hline & Knowledge/acquaintance with suppliers & Beattie \& Thomson, 2007 \\
\hline & Links with suppliers & $\begin{array}{l}\text { Beattie \& Thomson, 2007; Bozbura \& Beskese, 2007; Bozbura et al., 2007; Watson \& } \\
\text { Stanworth, 2006; Cabrilo et al., 2009; Peng et al., 2007; Asonitis \& Kostagiolas, 2010; } \\
\text { Chen, 2009; Ortiz, } 2009\end{array}$ \\
\hline & Negotiating capacity with financial entities & Beattie \& Thomson, 2007 \\
\hline & Outsourcing partners & Peng et al., 2007 \\
\hline
\end{tabular}

Relational capital has some components and indicators that vary in researches. It should be considered that these components and indicators are different in companies. This capital contains the 
relations with customers, shareholders, suppliers, rivals, the state, governmental institutions and society (Bozbura et al.,2007;Lee, 2010; Bozbura \& Beskese,2007).Meritum Project (2002) proposed that relational capital is defined by an organization's brand value, a strong network with customer, customer satisfaction, and royalty revenue. Interested external parties have a significant effect on the value of relational capital. Public R\&D organizations, for example, take advantage of interested external parties by their involvement in joint projects with universities and technology-intensive companies. Moreover, an organization's reputation increases the trust of customers or investors in the reliability of some technologies (Guerrero,2003). This kind of capital is related to the value that all the external relationships have for a company. It is concerned with establishment of strong ties between the organization and its customers (Brooks and Nafukho, 2006). The quality of the relationships and the ability to create new customers are key factors for the success of a company. The relations held with other agents such as the suppliers and the different alliances of the company are also a very important knowledge source. Relational capital includes indicators for measuring customer information, suppliers etc(Singh \& Kansal,2011). Ramezan(2011) proposed that relational capital gathers the value of the relationships that the firm maintains with external agents (business activity close by or with other more distant social agents(Ramezan,2011;Beattie \& Thomson, 2007).

Customer satisfaction and loyalty, handling customer, customer orientation, market share, and distribution channels may be indicators of customer capital (Bontis, 1998; Bontis et al., 2000; Engstrom et al., 2003). It is also constituted by customer satisfaction and loyalty, image and brand, and direct distribution channels (Kim et al.,2010).

Relational (Customer) capital includes both current value and potential future value of the organizational relationships with customers. Therefore, customer capital is in the tacit knowledge of marketing channels and customer relationships. Hence, it encompasses components such as brands, market share, customer information, relationships with customers, customers access points and business contracts (Bonits,2000).

\subsection{Structural Capital}

Structural (organizational) capital is the last common component of intellectual capital. Structural capital has been described as the backbone of the organization (Burr \& Girardi, 2002). It is knowledge that does not go home at night; it belongs to the organization as a whole. It can be reproduced and shared technologies, inventions, data, publications, and strategy and culture, structures and systems, organizational routines and procedures (Bukh et al., 2001). Structural capital plays an integral role in knowledge creation and management (Chang \& Birkett, 2004 ). Hsu \& Fang (2009) defines structural capital as including process capital and innovation capital. Martinez-Torres (2006) defines structural capital as the property of the organization, such as processes, information in a database, etc. Chang \& Birkett (2004) suggests that it refers to the combinations of formal and informal structures that support the use of human capital in an organization. Structural capital therefore conditions and contains how human capital is deployed, and codifies the residues of past uses of human capital as organizational knowledge. Structural capital represents the structures and cultures developed to support the use and enhancement of human and relational capital (Chang \& Birkett, 2004). Chang \& Birkett (2004) suggests that structural capital refers to the general system and procedures of the organization for problem-solving and innovation. It includes assessment of the stored knowledge value, the cycle of liquid capital, as well as accounting of administration expenses. Structural capital is defined as the structural ability of a firm to translate human capital innovation 
and energy into company property and to capitalize on that innovation to create wealth. Structural capital generally describes the general system and procedure for problem-solving and produces values in an organization, including the accounting-based value and accrued capital revolving rate (Chu et al., 2006). Embedded in organizations, structural capital was the supportive infrastructure of human capital (Chen, 2009). An enterprise with strong structural capital will create favorable conditions to utilize human capital and allow human capital to realize its fullest potential, and then to boost its innovation capital and customer capital. In detail, structural capital can be classified into company culture, organizational structure, organizational learning, operational process, and information system (Ramezan, 2011). Holton and Yamkovenko (2008) suggests that structural capital is referred to as a repository of knowledge that is accessible through various sources, which allows for knowledge sharing and knowledge creation among organizational members (Holton \& Yamkovenko, 2008). Structural capital is the support mechanism that enables employees to optimize their job performance and overall organizational performance (Liu, 2010).

After studying lots of papers, some definitions for structural capital were obtained. Table 6 represents these definitions.

\section{Table 6}

Structural (organizational) capital definitions

\begin{tabular}{|c|c|c|}
\hline No & Researchers & Definition \\
\hline 1 & Martinez-Torres , 2006 & $\begin{array}{l}\text { Organizational capital is" the sum of all assets pertaining to the firm, which } \\
\text { make the creative ability of the organization possible. The vision of the firm, } \\
\text { management philosophy, organization culture, strategies, processes, } \\
\text { working systems, and information technology can be mentioned among these } \\
\text { assets". }\end{array}$ \\
\hline 2 & Rudez \& Mihalic , 2007 & $\begin{array}{l}\text { Structural capital "is constituted by management philosophy, culture, business } \\
\text { processes and information technology in the hotel industry". }\end{array}$ \\
\hline 3 & Ramezan , 2011 & $\begin{array}{l}\text { Organizational capital is "the combination of explicit and implicit, formal and } \\
\text { informal knowledge which in an effective and efficient way to structure and } \\
\text { develop the organizational activity of the firm, that includes culture implicit } \\
\text { and informal knowledge , structure explicit and formal knowledge and } \\
\text { organizational learning implicit and explicit, formal and informal renewal } \\
\text { knowledge processes ". }\end{array}$ \\
\hline 4 & Chu et al. , 2006 & $\begin{array}{l}\text { The term structural capital refers to" the general system and procedures of the } \\
\text { organization for problem-solving and innovation. It includes assessment of the } \\
\text { stored knowledge value, the cycle of liquid capital , as well as accounting of } \\
\text { administration expenses". }\end{array}$ \\
\hline 5 & Ramezan , 2011 & $\begin{array}{l}\text { Structural capital "contains both organizational and technological elements that } \\
\text { pursue integration and coordination within the firm". }\end{array}$ \\
\hline 6 & Bozbura \& Beskese , 2007 & $\begin{array}{l}\text { Organizational capital is "the sum of all assets that make the creative ability of } \\
\text { the organization possible". }\end{array}$ \\
\hline 7 & Joia , 2007 & $\begin{array}{l}\text { Organizational capital components "refers to organisational culture, routines } \\
\text { and practices, or intellectual property". }\end{array}$ \\
\hline 8 & Beattie \& Thomson , 2007 & $\begin{array}{l}\text { Organizational capital is "the knowledge that stays within the firm at the end of } \\
\text { the working day. Comprises the organizational routines, procedures, systems , } \\
\text { cultures, databases, etc. Some may be legally protected and become } \\
\text { Intellectual Property Rights, legally owned by the firm under separate title". }\end{array}$ \\
\hline
\end{tabular}

Authors identified five categories for structural capital includes:

- Culture

- Knowledge based infrastructure

- Intellectual property

- Processes, Working Systems \& Routines

- Organization`s path

Indicators for these categories are represented in Table 7. 
Table 5

Indicators of each category for relational (customer) capital

\begin{tabular}{|c|c|c|}
\hline Category & Factor & Resources \\
\hline \multirow{3}{*}{ Culture } & Achieving mechanism culture & Beattie \& Thomson, 2007 \\
\hline & Corporate/Organizational culture & $\begin{array}{l}\text { Beattie \& Thomson, 2007; Cabrito et al., 2009; Kim \& Kunter, 2009; Peng et al., 2007; } \\
\text { Quthrie \& Petty, 2000; Singh \& Kansal, 2011; Ramezan, } 2011\end{array}$ \\
\hline & Cultural diversity & Beattie and Thomson, 2007 \\
\hline \multirow{8}{*}{$\begin{array}{l}\text { Knowledge- } \\
\text { based } \\
\text { infrastructure }\end{array}$} & Communication systems & Beattie \& Thomson, 2007; Peng et al., 2007; Kim et al., 2010; Cabrito et al., 2009 \\
\hline & Databases & Beattie \& Thomson, 2007; Bozbura \& Beskese, 2007; Cabrita et al., 2009 \\
\hline & Documentation services & Beattie \& Thomson, 2007 \\
\hline & Infrastructure & Beattie \& Thomson, 2007; Quthrie and Petty, 2000; Martin, 2000, Chen, 2009 \\
\hline & Knowledge centre & Beattie \& Thomson, 2007; Cabrito et al., 2009; Peng et al., 2007 \\
\hline & Specialized software/IT & Beattie \& Thomson, 2007; Rudez \& Mihalic, 2007; Cabrito et al., 2009 \\
\hline & Systems information/network & $\begin{array}{l}\text { Beattie \& Thomson, 2007; Ramezan, 2011; Tai \& Chen, 2009; Singh \& Kansal, 2011; Guthric } \\
\text { \& Petty, 2000; Peng et al., 2007; Kim \& Kunter , 2009; Wall, } 2005\end{array}$ \\
\hline & Organizational learning & Beattie \& Thomson, 2007; Ramezan, 2011; Peng et al., 2007; Kim \& Kunter, 2009 \\
\hline \multirow{8}{*}{$\begin{array}{l}\text { Intellectual } \\
\text { Property }\end{array}$} & Brands & Beattie \& Thomson, 2007; Cabrito et al., 2009; Tai \& Chen, 2009 \\
\hline & Copyrights & Beattie \& Thomson, 2007; Singh \& Kansal, 2011; Quthrie \& Petty, 2000 \\
\hline & Innovation & $\begin{array}{l}\text { Beattie \&Thomson, 2007; Peng et al., 2007; Kim \& Kunter, 2009; Wall 2005; Cabrito et al., } \\
2009\end{array}$ \\
\hline & Intellectual property & Beattie \&Thomson, 2007; Quthrie \& Petty, 2000 \\
\hline & Intellectual resources & Beattie \&Thomson, 2007 \\
\hline & Patents & $\begin{array}{l}\text { Beattie \&Thomson, 2007; Chen, 2009; Kim \& Kunter, 2009; Peng et al., 2007; Quthrie \& } \\
\text { Petty, 2007; Singh \& Kansal, } 2011\end{array}$ \\
\hline & Research projects & Beattie \& Thomson 2007, cabrito et al 2011 \\
\hline & Trademarks & $\begin{array}{l}\text { Beattie \& Thomson, 2007; Cabrito et al., 2009; Chen, 2009; Quthric \& Petty, 2000; Singh \& } \\
\text { Kansal, 2011; Tai \& Chen, } 2009\end{array}$ \\
\hline \multirow{16}{*}{$\begin{array}{c}\text { Processes, } \\
\text { Working } \\
\text { Systems \& } \\
\text { Routines }\end{array}$} & Administrative processes & Beattie \& Thomson, 2007 \\
\hline & Organizational flexibility & Beattie \& Thomson, 2007; Peng et al., 2007 \\
\hline & $\begin{array}{l}\text { Competitive and market channels \& } \\
\text { Distribution channels }\end{array}$ & Beattie \& Thomson, 2007 \\
\hline & Customer support & Beattie \& Thomson, 2007 \\
\hline & Financial relations & Beattie \& Thomson, 2007; Peng et al., 2007; Quthrie \& Petty, 2000; Singh \& Kansal, 2011 \\
\hline & Laboratories & Tai and Chen, 2009; Kim \& Kunter, 2009 \\
\hline & Management processes & Beattie \& Thomson, 2007; Peng et al., 2007 \\
\hline & Operation process & Beattie \& Thomson, 2007; Singh \& Kansal, 2011; Quthrie \& Petty, 2000 \\
\hline & Organizational routines & Beattie \& Thomson, 2007; Ramezan, 2011; Peng et al., 2007 \\
\hline & Procedures & Beattie \& Thomson, 2007; Kim et al., 2010; Martin, 2000; Peng et al., 2007 \\
\hline & Process capability & Beattie \& Thomson, 2007; Rudez \& Mihalic, 2007 \\
\hline & Index of productivity & Beattie \& Thomson, 2007; Wall, 2005; Kim \& Kunter, 2009 \\
\hline & Quality improvements & Beattie \& Thomson, 2007 \\
\hline & Quality management & Beattie \& Thomson, 2007 \\
\hline & Management system & Kim \& kunter, 2009; Bozbura \& Beskes, 2007 \\
\hline & Organizational structure & Beattie \& Thomson 2007; Ramezan, 2011; Peng et al., 2007 \\
\hline \multirow{3}{*}{$\begin{array}{l}\text { Organization } \\
\text { `s path }\end{array}$} & Strategy & Beattie \& Thomson, 2007 \\
\hline & Management philosophy & $\begin{array}{l}\text { Beattie \& Thomson, 2007; Singh \& Kansal, 2011; Quthrie \& Petty, 2000; Rudez \& Mihalic, } \\
2007\end{array}$ \\
\hline & Mission/vision & Kim \& Kunter, 2009; Peng et al., 2007; Bozbura \& Beskes, 2007 \\
\hline
\end{tabular}

\section{Conclusions}

As Chu et al. (2006) mentioned, the components of intellectual capital indicate firm future value and the ability to generate financial results. In other words, today, intangible assets of an organization play a key role in creating wealth for companies. Intangible assets and especially intellectual capital is an undeniable part of organization market value. Maybe it could be said that intangible asset and intellectual capital have a great effect on the market value of every organization. However, up to now there is no single best solution because each method has its pros and cons (Lu et al.,2010, Wall, Kirk \& Martin,2004). Using definitions from previous studies, some categories were identified for three common components. Human capital categories are:

- Attitude \& Motivation

- Competence, Skill, Capabilities

- Creativity \& Innovativeness

- Experience \& Expertise

- Individual personal characteristics 
- Knowledge

- Efficiency

Relational Capital categories are:

- Customers

- Stakeholders

- Corporate identity

- Internal issues

- Market Presence and Business Contracts

- Suppliers

Structural capital categories are:

- Culture

- Knowledge based infrastructure

- Intellectual property

- Processes, Working Systems \& Routines

- Organization`s path

Every organization should select its appropriate intellectual capital definition and its indicators to measure it. Right selection of indicators is a critical issue for organization to know about their intellectual capital index. For the goal of this paper, lots of papers have been studied by the authors. It is agreed that there is no common definition for intellectual capital. Many indicators were recognized during the study, but they re not appropriate for all of organizations. Therefore, the most important part of every study to measure intellectual capital is picking the right indicators for that organization.

\section{References}

Alcaniz, L., Bezares, F. G., \& Roslender, R. (2011). Theoretical perspectives on intellectual capital: A backward look and a proposal foregoing forward. Article in press. Accounting Forum.

Andriessen, D. (2004). Making Sense of Intellectual Capital: Designing a Method for the Valuation of Intangibles, Elsevier Butterworth-Heinemann, Burlington, MA.

Andriessen, D. (2007). Designing and Testing an OD Intervention : Reporting Intellectual Capital to Develop Organizations. Journal of Applied Behavioral Science, 43, 89-107.

Asonitis, S., \& Kostagiolas, P. A. (2010). An analytic hierarchy approach for intellectual capital: Evidence for the Greek central public libraries. Library Management, 31(3), 145-161.

Baker, R. J. (2008), Mind Over Matter: why intellectual capital is the chief source of wealth, John Wiley \& Sons, Hoboken, New Jersey.

Bartholomew, D. (2008). Building on Knowledge: Developing Expertise, Creativity and Intellectual Capital in the Construction Professions, Wiley-Blackwell, Singapore.

Beattie, V., \& Thomson, S. J. (2007). Lifting the lid on the use of content analysis to investigate intellectual capital disclosures. Accounting Forum, 31, 129-163.

Bontis, N. (1998). Intellectual capital: an exploratory study that develops measures and models", Management Decision, 36(2), 63.

Bontis, N. (2001). Assessing knowledge assets: a review of the models used to measure intellectual capital. International Journal of Management Reviews, 3(1), 41-60.

Bozbura, F. T., \& Beskese, A. (2007). Prioritization of organizational capital measurement indicators using fuzzy AHP. International Journal of Approximate Reasoning, 44, 124-147.

Bozbura, F. T., Beskese, A., \& Kahraman, C. (2007). Prioritization of human capital measurement indicators using fuzzy AHP. Expert Systems with Applications, 32, 1100-1112 
Bukh, P.N., Larsen, H.T., \& Mouritsen, J. (2001). Constructing intellectual capital statements. Scandinavian Journal of Management, 17, 87-108.

Burr, R., \& Girardi, A. (2002). Intellectual capital: More than the interaction of competence $\mathrm{x}$ commitment. Australian Journal of Management, 27, 77-87.

Cabrilo, S., Uzelac, Z., \& Cosic, I. (2009). Researching indicators of organizational intellectual capital in Serbia. Journal of Intellectual Capital, 10(4), 573-587.

Chang, L., \& Birkett, B. (2004). Managing intellectual capital in a professional service firm: exploring the creativity-productivity paradox. Management Accounting Research, 15, 7-31.

Chen, S. Y. (2009). Identifying and prioritizing critical intellectual capital for e-learning companies. European Business Review, 21(5), 438-452.

Chu, P. Y., Lin, Y. L., Hsiung, H. H., \& Liu, T. Y. (2006). Intellectual capital: An empirical study of ITRI. Technological Forecasting \& Social Change, 73, 886-902.

Doong, S. C., Fung, H. G., \& Wu, J. Y. (2011). Are social, financial, and human capital value enhancing? Evidence from Taiwanese firms. International Review of Economics and Finance, 20(3), 395-405.

Gavious, I., \& Russ, M. (2009). The valuation implications of human capital in transactions on and outside the exchange. Advances in Accounting, incorporating Advances in International Accounting, 25, 165-173.

Guerrero, I. (2003). How do firms measure their intellectual capital? Defining an empirical model based on firm practices. International Journal of Management \& Decision Making, 4(2-3), 178193.

Guthrie, J., \& Petty, R. (2000). Intellectual capital: Australian annual reporting practices. Journal of Intellectual Capital, 1(3), 241-251.

Han, D., \& Han, I. (2004). Prioritization and selection of intellectual capital measurement indicators using analytic hierarchy process for the mobile telecommunications industry. Expert Systems with applications, 26, 519-527.

Holton, E. F. \& Yamkovenko, B. (2008). Strategic intellectual capital development: A defining paradigm for HRD? Human Resource Development Review, 7(3), 270-291.

Hsu, Y. H., \& Fang, W. (2009). Intellectual capital and new product development performance: The mediating role of organizational learning capability. Technological Forecasting \& Social Change, 76, 664-677.

Joia, L. A. (2007), Strategies for Information Technology and Intellectual Capital: Challenges and Opportunities, Information science reference, Hershey,PA.

Kim, D. Y., \& Kumar, V. (2009). A framework for prioritization of intellectual capital indicators in R\&D. Journal of Intellectual Capital, 10(2), 277-293.

Kim, D. Y., \& Kumar, V. (2009). A framework for prioritization of intellectual capital indicators in R \& D. Journal of Intellectual Capital, 10(2), 277-293.

Kim, T. , Yoo, J. J. E., \& Lee, G. (2010). The HOINCAP scale: measuring intellectual capital in the hotel industry. The Service Industries Journal, First published on: 28 September 2010 (iFirst).

Kitts, B., Edvinsson, L., \& Beding, T. (2001). Intellectual capital: from intangible assets to fitness landscapes. Expert Systems with Applications, 20, 35-50.

Lee, S. H. (2010). Using fuzzy AHP to develop intellectual capital evaluation model for assessing their performance contribution in a university. Expert Systems with Applications, 37, 4941-4947.

Lee, S. H. (2010). Using fuzzy AHP to develop intellectual capital evaluation model for assessing their performance contribution in a university. Expert Systems with Applications, 37, 4941-4947.

Lim, L. L. K., Chan, C. C. A., \& Dallimore, P. (2010). Perceptions of Human Capital Measures: From Corporate Executives and Investors. Journal of Business Psychology, 25, 673-688.

Liu, C. C. (2010). Prioritizing enterprise environment management indicators by intellectual capital perspective. The Journal of International Management Studies, 5(2), 110-117. 
Lu, W. M., Wang, W. K., Tung, W. T., \& Lin, F. (2010). Capability and efficiency of intellectual capital: The case of fabless companies in Taiwan. Expert Systems with Applications, 37, 546555.

Luo, X. R., Koput, K. W., \& Powell, W. W. (2009). Intellectual capital or signal? The effects of scientists on alliance formation in knowledge-intensive industries. Research Policy, 38, 13131325.

Lytras, M. D., \& Pablos, P. O. (2009). Knowledge Ecology in Global Business: Managing Intellectual Capital. Information science reference, Hershey, PA.

Martin, W. J. (2000). Approaches to the measurement of the impact of knowledge management programmes. Journal of Information Science, 26(21), 21-27.

Martinez-Torres, M.R. (2006). A procedure to design a structural and measurement model of intellectual capital: An exploratory study. Information \& Management, 43, 617-626.

Мeca, E. G., \& Martinez, I. (2007). The use of intellectual capital information in investment decisions: An empirical study using analyst reports. The International Journal of Accounting, 42, 57-81.

Montequín, V. R., Fernández, F. O., Cabal, V. A., \& Gutierrez, N. R. (2006). An integrated framework for intellectual capital measurement and knowledge management implementation in small and medium-sized enterprises. Journal of Information Science, 32(6), 525-538.

Mouritsen, J., Larsen, H.T., \& Bukh, P.N.D. (2001). Intellectual capital and the 'capable firm': narrating, visualising and numbering for managing knowledge. Accounting, Organizations and Society, 26, 735-762.

Ortiz, M. M. A. (2009). Analysis and valuation of intellectual capital according to its context. Journal of Intellectual Capital, 10(3), 451-482.

Peng, T. J. A., Pike, S., \& Roos, G. (2007). Intellectual capital and performance indicators: Taiwanese healthcare sector. Journal of Intellectual Capital, 8(3), 538-556.

Peppard, J., \& Rylander, A. (2001). Using an Intellectual Capital Perspective to Design and Implement a Growth Strategy: The Case of APiON. European Management Journal, 19(5), 510525.

Ramezan, M. (2011). Intellectual capital and organizational organic structure in knowledge society: How are these concepts related? International Journal of Information Management, 31, 88-95.

Ricceri, F. (2008). Intellectual Capital and Knowledge Management Strategic management of knowledge resources. Routledge, New York, NY.

Rudez, H. N., \& Mihalic, T. (2007). Intellectual capital in the hotel industry: A case study from Slovenia. Hospitality Management, 26, 188-199.

Singh, S., \& Kansal, M. (2011). Voluntary disclosures of intellectual capital: An empirical analysis. Journal of Intellectual Capital, 12(2), 301-318.

Smart, G. H. (1999). Management assessment methods in venture capital: An empirical analysis of human capital valuation. Venture Capital, 1(1), 59 - 82.

Tai, W. S., \& Chen, C. T. (2009). A new evaluation model for intellectual capital based on computing with linguistic variable. Expert Systems with Applications, 36, 3483-3488.

Wall, A. (2005). The measurement and management of intellectual capital in the public sector. Public Management Review, 7(2), 289-303.

Wall, A., Kirk, R., \& Martin, G. (2004). Intellectual Capital: Measuring the Immeasurable? CIMA Publishing, Oxford.

Watson, A. \& Stanworth, J. (2006). Franchising and intellectual capital: A franchisee's perspective. Entrepreneurship Management, 2, 337-349.

Yang, C. C., \& Lin, C. Y. Y. (2009). Does intellectual capital mediate the relationship between HRM and organizational performance? Perspective of a healthcare industry in Taiwan. The International Journal of Human Resource Management, 20(9), 1965-1984.

Zula, K. J., \& Chermack, T. J. (2007). Integrative literature review: Human capital planning: A review of literature and implications for human resource development. Human Resource Development Review, 6, 245-262. 